\title{
MOŻLIWOŚCI EKUMENICZNYCH OBCHODÓW JUBILEUSZU 500-LECIA REFORMACJI - PRZESZKODY, SZANSE I WYZWANIA
}

Chrześcijanie trzeciej wielkiej rodziny wyznaniowej, czyli protestantyzmu, przygotowują się już od kilku lat do obchodów Jubileuszu 500-lecia reformacji. Słowami-kluczami tych przygotowań są określenia „Dekada reformacji”, „Dekada Lutra”, „Rok 2017”, Luter2017”, „Refo500”. Jubileusz ma w różnych krajach własną, oryginalną typografię, a nawet księgę logotypów. Przygotowania mają wybitnie medialny i szeroko pojęty promocyjny charakter. Z polskiej strony internetowej www.luter2017.pl możemy się np. dowiedzieć, że do „tego dnia” zostało jeszcze 999 dni. ${ }^{1} \mathrm{Na}$ forum Synodu Kościoła Ewangelicko-Augsburskiego w RP oraz praktycznie we wszystkich kościelnych gremiach próbuje się wypracować formułę, jak ten jubileusz ma wyglądać, jak go ukształtować, jakie ma przybrać formy. Ważnym zagadnieniem owych przygotowań jest poszukiwanie możliwej ekumenicznej formuły obchodów tego bez wątpienia szczególnego dla zachodniego chrześcijaństwa wydarzenia.

Pierwszy, okrągły jubileusz reformacji, czyli obchodzone w 1617 r. stulecie wystąpienia Marcina Lutra, stał się asumptem do poważnego zbliżenia luteran i reformowanych. Jednocześnie owa wewnątrz ewangelicka konsolidacja i wyrażenie solidarności nadało ówczesnym obchodom polemiczny, antykatolicki wymiar, ukazujący dzieło reformacji XVI w., jako wyzwolenie chrześcijan spod jarzma papiestwa. ${ }^{2}$

www.luter2017.pl/ (dostęp: 5 II 2015).

2 Od konfliktu do komunii. Luterańsko-katolickie upamiętnienie Reformacji w 2017 roku. Raport luterańsko-rzymskokatolickiej Komisji Dialogu ds. Jedności, tłum. D. B r u n c z, Dzięgielów 2013, s. 14. 
Kolejne jubileusze odkrywały inne wymiary protestantyzmu, nie zawsze pozytywne. Rok 1817 przyniósł na terenie Prus unię kościelną, która miała połączyć luteran i ewangelików reformowanych (kalwinistów) w jednym Kościele Ewangelicko-Unijnym. Z perspektywy teologicznej, był to pomysł uczczenia wielkiego jubileuszu autorstwa Fryderyka D. E. Schleiermachera, w realizacji była to decyzja administracyjna króla pruskiego Fryderyka Wilhelma III (1770-1840). Wywołało to gwałtowne, wręcz burzliwe sprzeciwy ze strony sporej liczby luteran. ${ }^{3}$ Również niemieckie obchody kolejnego jubileuszu reformacji, to jest w $1917 \mathrm{r}$., nadały uroczystościom nowy, tym razem, niestety, nazbyt narodowy wymiar, ukazując ks. dr. Marcina Lutra jako niemieckiego wyzwoliciela i bohatera narodowego, gubiąc tym samym jego duchowy i kościelny charakter.

Dla działań zjednoczeniowych w świecie luterańskim i to głównie w kontekście amerykańskim, to nie jubileusz reformacji w 1917 r., lecz I wojna światowa i jej konsekwencje, stały się impulsem na rzecz budowy światowej organizacji luteran. ${ }^{4}$ Jak podkreśla polski badacz ekumenizmu, Karol Karski, „Kościoły luterańskie żyły przez całe stulecia własnym życiem, nie interesując się zbytnio losem współwyznawców w innych krajach albo na innych kontynentach. Dążenia zmierzające do ściślejszej współpracy w dziedzinie teologii i pomocy wzajemnej pojawiły się dopiero w drugiej połowie XIX stulecia". ${ }^{5}$

Protestanci na całym świecie szykują się do piątego okrągłego jubileuszu wydarzenia założycielskiego dla trzeciej wielkiej rodziny konfesyjnej chrześcijaństwa. Jaki wymiar będą miały te obchody? Czy będzie to odejście od dotychczasowych kierunków świętowania rocznicy ogłoszenia przez Lutra $95 \mathrm{Tez}$ przeciw odpustom i nadanie temu wydarzeniu po raz pierwszy w historii prawdziwie

3 Ów ruch protestu doprowadził do wyodrębnienia się Kościoła staroluterskiego.

4 M. H i n t z, Rozumienie wspólnoty kościelnej w ewangelicyzmie. Światowa Federacja Luterańska jako rozwinięcie wizji eklezjologicznej Reformacji? Gdański Rocznik Ewangelicki t. VI, 2012, s. 180.

5 K. K a r s k i, Luteranizm $w$ dialogu, Studia i Dokumenty Ekumeniczne 45(2000)1, s. 11. 
ekumenicznego wymiaru? By tak się mogło stać, musi zostać spełnionych kilka warunków. Przygotowania obecne w Polsce, jak też na terenie Niemiec, zbytnio koncentrują się na aspektach promocyjnych i wizerunkowych.

Dlatego niniejsza analiza wskazuje inny kierunek. Pierwszym jej etapem jest próba odpowiedzi na pytania o tożsamość ewangelicką drugiej dekady XXI w. w Polsce i na świecie w kontekście ekumenicznego zaangażowania.

\section{Tożsamość luterańska - tożsamość ewangelicka - tożsamość chrześcijańska}

Pytanie o tożsamość, jej zakres, wyróżniki, styczne i rozłączne, to najważniejsze zagadnienie w kontekście duchowych obchodów reformacyjnego jubileuszu. To pytanie o prawdziwe dziedzictwo tego, co się wydarzyło przed 500 laty w Wittenberdze, Strasburgu, Zurychu i Genewie. A później, znalazło tak głęboki oddźwięk w królewskim Gdańsku, Poznaniu, Trzebiatowie czy Cieszynie. Pojawił się nowy typ duchowości i tożsamości chrześcijańskiej.

W popularnej w Niemczech książce Hansa-Michaela Uhla, zatytułowanej Das ist evangelisch. Zehn Merkmale des protestantischen Lebens, znajdujemy próbę samookreślenia współczesnej ewangelickiej tożsamości. Autor rozpoczyna swe rozważania od znamiennego sformułowania: „Obecnie w epoce ekumenizmu i dialogu religijnego jest wyjątkowo ważnym, by na nowo sformułować pytanie, co w danej religii i wyznaniu jest charakterystyczne $\mathrm{i}$ atrakcyjne $\mathrm{i}$... by na to pytanie odpowiedzieć". 6 Tym samym dla niemieckiego duchownego pojęcie „ekumenizm” określa właściwy kontekst współczesnych pytań o tożsamość wyznaniową. Na ten aspekt wskazują również autorzy bardzo popularnego w Niemczech, ekumenicznego opracowania:

6 H.-M. U h 1, Das ist evangelisch. Zehn Merkmale des protestantischen Lebens, Freiburg-Basel-Wien 2012, s. 7. 
Typisch katholisch - typisch evangelisch. ${ }^{7}$ Każdy artykuł napisany jest przez dwóch autorów, jednego teologa ewangelickiego i jednego katolickiego, ukazuje różne elementy współczesnej chrześcijańskiej tożsamości epoki ekumenizmu.

Te dwa impulsy przywołane z kontekstu niemieckiego, który też zresztą nie ma jednorodnego charakteru, stanowią punkt odniesienia dla polskiej dyskusji. Ekumenizm w Niemczech jest także wciąż w fazie przejściowej: od pierwotnego entuzjazmu do aktualnego stanu ,ekumenizmu profili” - jak określił to Benedykt XVI w 2005 r. ${ }^{8}$

Wiele elementów niemieckiej debaty znajduje swe odzwierciedlenie w sformułowaniach polskich teologów. Dlatego ważniejsze wydaje się odwołanie do polskiej dyskusji. Obecnie trudno wskazać na szczególnie ważne teksty dotyczące tożsamości polskich luteran. Należy sięgnąć do dyskusji, która odbywała się przed 10 laty, gdy Kościół luterański w RP przeżywał rok tożsamości ewangelickiej. Ukazały się wtedy niezwykle inspirujące artykuły osób, które kształtowały i nadal kształtują dzisiejsze życie luterańskiego Kościoła w Polsce. ${ }^{9}$

W Kalendarzu Ewangelickim na rok 2002 zamieszczono referaty wygłoszone podczas Ogólnopolskiej Konferencji Teologicznej Duchownych Kościoła Ewangelicko-Augsburskiego w RP, jak też przedłożenia wygłoszone podczas Synodu Diecezji Katowickiej oraz referaty z jesiennej sesji Synodu Kościoła 2001 r.

Referat autorstwa ks. Tadeusza Makuli Rola duchownego i jego rodziny $w$ ksztaltowaniu tożsamości ewangelickiej jest wyrazem nostalgii za odchodzącą do przeszłości rzeczywistością, czyli tradycyjnego ewangelicyzmu ludowego występującego na Śląsku Cieszyńskim. Autor nawiązuje do tekstu bp. Karola Kotuli zatytułowanego

7 M. Me y e r-B l a n c k, W. F ü r s t (red.), Typisch katholisch-typisch evangelisch. Ein Leitfaden für die Ökumene im Alltag, Rheinbach 2003.

${ }^{8}$ W. H u b e r, Choreographie der Ökumene, w: M. K e u c h e n, M. L e n z, M. L e u t z s c h (red.), Tanz und Religion: Theologische Perspektiven, Frankfurt am Main, 2008, s. 201.

9 W poniższej analizie odwołuję się do wyników badań własnych przedstawionych w artykule: M. H in t z, Rok poszukiwań tożsamości wyznaniowej polskiego luteranizmu, Myśl Protestancka 1/2002, s. 45-54. 
Duchowny, rodzina i dom, ${ }^{10}$ kreśląc wizję idyllicznej posługi księdza ewangelickiego dbającego o duchowy wzrost zboru.

Autorami kolejnych dwóch ważnych tekstów sprzed dekady są bp Tadeusz Szurman (wówczas prezes Synodu KEA) oraz ks. Marian Niemiec.

Ksiądz Szurman umiejscawia dyskusję na temat tożsamości człowieka wiary w kontekście tragicznych wydarzeń z 11 września 2001 r., które miały miejsce w Nowym Jorku. ${ }^{11}$ Wskazuje tym samym na globalny wymiar naszej egzystencji i pobudza do spojrzenia na paradygmat ewangelickiej tożsamości w szerszej optyce, nie tylko z punktu widzenia codziennych sporów i dylematów.

Ksiądz Niemiec próbuje wskazać kolejne kręgi naszej tożsamości. Autor wskazuje, że po pierwsze jest chrześcijaninem, co nadaje uniwersalny wymiar naszej tożsamości. Dalej stwierdza: jestem luteraninem, określając to mianem wymiaru partykularnego. Ksiądz Niemiec definiuje też via negationis, czym Kościół nie jest: firmą, stowarzyszeniem, organizacją społeczną, a „tylko dla pewnego porządku kieruje się ludzkimi przepisami i prawami". ${ }^{12}$ Autor nawiązuje następnie do stanowczych słów Marcina Lutra wygłoszonych na Sejmie w Wormacji: „Oto stoję, inaczej nie mogę” oraz do reformacyjnych haseł sola. Kończy swe przemyślenia wyznaniem: „Jezus jest moim Panem, a ja idę za nim niosąc swój krzyż, który jest brzemieniem miłym i lekkim". ${ }^{13}$ Artykuł ten, będący pierwotnie referatem konferencyjnym, jest świadectwem wiary świadomego swych zadań ewangelickiego duchownego diaspory i pokazuje kierunki tożsamościowych poszukiwań pomiędzy tym, co ogólne, chrześcijańskie,

10 T. M a k u l a, Rola duchownego i jego rodziny w ksztaltowaniu tożsamości ewangelickiej, w: Kalendarz Ewangelicki 2002. Ewangelizacja i tożsamość, Bielsko-Biała 2002, s. 209.

11 T. S z u r m a n, Czy istnieje konfesyjna tożsamość ewangelicka? w: tamże, s. 216.

12 M. N i e m i e c, Tożsamość wyznaniowa-jestem chrześcijaninem, jestem luteraninem, w: tamże, s. 223.

13 Tamże, s. 224. 
a tym, co konfesyjne. Tym samym autor twierdzi, że niemożliwe jest budowanie swej tożsamości bez ekumenicznego kontekstu.

Artykuł ks. Piotra Szarka próbuje się zmierzyć z pytaniami formułowanymi przez światowy luteranizm. Autor rozpoczyna od pytania, na czym polega sama istota tożsamości, czyli pyta: Kim jestem przede wszystkim? ${ }^{14}$ Odpowiedź ma charakter negatywny: przede wszystkim jestem nikim.

Ale tak właśnie powinna brzmieć odpowiedź na to pytanie na gruncie luterańskiej, reformacyjnej antropologii: ,Jestem nikim!”, to znaczy właśnie: jestem tylko człowiekiem, czyli jestem grzesznikiem. To rodzaj tożsamości negatywnej, ale, jak zaznacza autor, nie jest to rodzaj tożsamości negatywnej wobec innych, odgraniczającej się, jeśli już to próbującej odgraniczyć się od grzechu. To nie jest również rodzaj negacji w stosunku do innego Kościoła, czy szerzej innej grupy ludzi. „Jesteśmy tylko grzesznikami” - to przecież tak często cytowane słowa Marcina Lutra. ${ }^{15}$ Następnie, opierając się na tezie wyjściowej nawiązującej do reformacyjnej antropologii, ks. Szarek ukazuje wyznaczniki luterańskiej tożsamości w polskim kontekście. Są to: teologia diaspory; zdolność do twórczej służby; powszechność, różnorodność, jedność; duchowe skarby i żywa wiara. Autor odwołuje się do powszechnego występowania specyficznie luterańskich kompleksów, w których tak głęboko bywamy zakorzenieni. ${ }^{16}$

Warto przywołać w tym miejscu jeszcze kolejny głos autorstwa wybitnego ekumenisty śląskiego, bp. Szurmana, który rozważania o tożsamości wyznaniowej polskiego luteranizmu umieścił między dwoma biegunami, jakimi są z jednej strony wąski konfesjonizm, a z drugiej ekumenizm. ${ }^{17}$ Konfesjonizm, zdaniem autora, oznacza przywiązanie, czasami zbyt sztywne do zewnętrznych wyznaczników

14 P. S z a r e k, Teologiczne wyznaczniki luterańskiej tożsamości, w: tamże, s. 225 .

15 Tamże.

16 Tamże, s. 230.

17 T. S z u r m a n, Tożsamość ewangelicka dzisiaj - konfesjonizm czy ekumenizm? Zwiastun Ewangelicki 10/2001, s. 8-10. 
danego wyznania, co w sytuacji polskiego luteranizmu rodzi problemy, gdyż występuje w nim ,zbyt wielka różnorodność poglądów samych ewangelików od pietyzmu... do liberalizacji i ateizacji". ${ }^{18}$ Ksiądz Szurman analizuje następnie zewnętrzne zagrożenia dla tożsamości wyznaniowej i przedstawia własną propozycję: „Od konfesjonizmu do tożsamości otwartej" ${ }^{19}$ To propozycja odwołująca się do przeszłości, po to, by budować przyszłość. Artykuł kończy się 10 wnioskami, które można określić jako dekalog luterańskiej tożsamości wyznaniowej. Model zaprezentowany przez ks. Szurmana próbuje się więc sytuować gdzieś w środkowym nurcie owych typów pobożności wymienionych powyżej i jest propozycją luteranizmu świadomego swych wartości, podkreślającego własną tradycję, lecz zarazem otwartego na dialog i uprawiającego świadomy, refleksyjny ekumenizm.

\section{Bilateralne dialogi ekumeniczne prowadzone przez luteran}

By możliwa była dyskusja na temat szansy ekumenicznych obchodów 500-lecia reformacji należy najpierw wskazać możliwych partnerów takiej debaty.

Kościół luterański należy dzisiaj do najbardziej aktywnych uczestników ruchu ekumenicznego. Jest jednym z jego koryfeuszy i promotorów. Jednak nie zawsze tak było. Przywołany już K. Karski twierdzi mianowicie: „Ogólnie można powiedzieć, że luteranizm jako rodzina Kościołów o silnej świadomości wyznaniowej odkrywał bardzo powoli i stopniowo swoje ekumeniczne zobowiązanie. Dziś znaczna część Kościołów luterańskich jest członkami różnych międzynarodowych organizacji ekumenicznych". ${ }^{20}$

VI Zgromadzenie Ogólne Światowej Federacji Luterańskiej, obradujące w Dar es Salaam w Tanzanii w 1977 r., sformułowało ostatecznie koncepcję ekumenizmu znaną jako ,jedność w pojednanej różnorodności”. Wizja ta stała się obecnie wspólnym dobrem całego

\footnotetext{
18 Tamże, s. 8.

19 Tamże, s. 9.

${ }^{20}$ K. K a r s k i, Luteranizm $w$ dialogu, s. 15.
} 
ruchu ekumenicznego. Formuła ta kreśli drogę do jedności, podczas której poszczególne strony dialogu nie muszą rezygnować z własnej tradycji i tożsamości. Dokument końcowy Zgromadzenia stwierdza: „Jest to droga żywego spotkania, duchowego doświadczenia, teologicznego dialogu i wzajemnej korekty, przy czym różnice nie ulegają zatarciu, ale także nie bywają konserwowane i utrzymywane w niezmienionym stanie". ${ }^{21}$

Bez wątpienia, najważniejszym i najdonioślejszym z wielu względów dialogiem teologicznym luteran jest ten prowadzony z Kościołem rzymskokatolickim, co poddamy analizie w dalszej partii artykułu.

Szczególne miejsce zajmuje też współpraca luteran z anglikanami w ramach Konferencji z Porvoo, która powstała w Finlandii w 1992 r. w Järvenpää. W Porvoo odprawiono wspólne nabożeństwo z komunią św. - od tego pochodzi późniejsza nazwa Wspólnoty. Porozumienie z Porvoo jest deklaracją jedności religijnej Kościołów anglikańskich i luterańskich nordyckich oraz wyrazem ich jedności z tzw. Starym Kościołem, istniejącym przed wydarzeniem reformacji. Kościoły będące we wspólnocie uważają się za części jednego Kościoła powszechnego i apostolskiego, które, mimo oddzielenia od papiestwa, oparte są na sukcesji apostolskiego urzędu. ${ }^{22}$

Z Kościołami reformowanymi i metodystycznymi luteranie w Europie stanowią Wspólnotę Kościołów Ewangelickich Europy (GEKE). Wspólnota została założona w 1974 r. i do 2003 r. funkcjonowała jako Leuenberska Wspólnota Kościołów, od nazwy ugody, jaką jest Konkordia Leuenberska, dokument podpisany 16 marca 1973 r. w szwajcarskim Leuenbergu przez większość europejskich Kościołów luterańskich i reformowanych oraz Kościoły ewangelicko-unijne, waldensów i braci czeskich. Konkordia prezentuje wspólne stanowisko w kwestiach dotąd dzielących wyznania ewangelickie, to jest ukazuje pojmowanie chrztu, Wieczerzy Pańskiej, predestynacji,

${ }_{21}$ Daressalam 1977. Sechste Vollversammlung des Lutherischen Weltbundes, Frankfurt/M. 1977, s. 205.

22 The Porvoo Statement, 1992, www.porvoocommunion.org/porvoo_communion/statement/the-statement-in-english/ (dostęp: 20 X 2014). 
chrystologii, umożliwiające wprowadzenie wspólnoty ołtarza i ambony. ${ }^{23} \mathrm{~W}$ tym przypadku możemy mówić wręcz nie o dialogu ekumenicznym, lecz o kościelnej wspólnocie, która istnieje w Polsce. ${ }^{24}$ Można więc powiedzieć, że historyczne Kościoły protestanckie będą razem świętować jubileusz 500-lecia reformacji.

Zupełnie nieznany szerszym kręgom jest dialog luterańsko-prawosławny, dlatego chciałbym poświęcić mu teraz uwagę, gdyż zwykle podkreśla się ostrożność prawosławia wobec ruchu ekumenicznego. ${ }^{25}$

Pierwszym istotnym głosem prawosławia w kwestii ekumenizmu jest słynna encyklika Patriarchatu Ekumenicznego z 1902 r., adresowana do wszystkich siostrzanych Kościołów prawosławnych. Jest to apel o bardziej dynamiczną współpracę na gruncie koncyliaryzmu. ${ }^{26}$ Wówczas oficjalny dialog z Kościołem rzymskokatolickim, ani też z którymkolwiek ewangelickim nie został rozpoczęty. Jednak patriarcha Joachim III deklaruje wiarę, że to, co nie jest możliwe u ludzi, jest możliwe u Boga.

W 1920 r. nieobsadzony personalnie patriarchat ekumeniczny wraz z jedenastoma innymi metropolitami ogłosił encyklikę adresowaną „do Kościołów Chrystusa, które są na całym świecie”. Dokument ten napisany bezpośrednio po zakończeniu I wojny światowej apeluje do chrześcijaństwa zachodniego o rezygnację z prozelityzmu i uniatyzmu, jednocześnie postulując utworzenie eklezjalnej wspólnoty, mającej służyć sobie wzajemną pomocą. ${ }^{27}$ Encyklika, rozpoczyna się od słów, że koinonia między Kościołami chrześcijańskimi jest niezbędna. ${ }^{28}$

23 Konkordia Leuenberska, tłum. pol.: www.leuenberg.eu/fr/node/599.

24 Luteranie-reformowani, www.luteranie.pl/o_naszym_kosciele/informacje_o_ kosciele/luteranizm_w_dialogu/luteranie_reformowani.html (dostęp: 21 X 2014).

25 Poniżej odwołuję się do wyników badań ks. Romana Prackiego: R. P r a c k i, Luteranie i prawosławni w dialogu. Studium historyczno-krytyczne (praca doktorska w ChAT, Warszawa 2014).

26 K. L e ś n i e w s k i, Jedność chrześcijan w oficjalnych wypowiedziach Kościoła prawosławnego, Sympozjum 1 (6)2000, Kraków 2000, s. 23.

27 A. W e is s, Ekumeniczny Patriarchat Prawosławny, w: Encyklopedia Katolicka, t. 4, Lublin 1983, s. 850-851.

28 R. P r a c k i, Luteranie i prawosławni w dialogu, s. 41. 
Kolejnym ważnym krokiem prawosławia w kierunku dialogu ekumenicznego była encyklika Patriarchatu Ekumenicznego z 1952 r., wydana w związku z trzecią konferencją Komisji Wiara i Ustrój, obradującej w szwedzkim Lund. Encyklika nawołuje do wzajemnego zbliżenia i podejmowania współpracy ze wszystkimi wyznaniami oraz organizacjami chrześcijańskimi, co jest świętym obowiązkiem i powinnością każdego chrześcijanina. Dokument podkreśla, że prawosławie zamierza podzielić się posiadanym przez siebie skarbem wiary i kultu, by w ten sposób wzbogacić społeczność całej Światowej Rady Kościołów, w pracach której patriarchat konstantynopolitański na początku uczestniczył w charakterze obserwatora.

Początki bezpośrednich kontaktów ekumenicznych Światowej Federacji Luterańskiej i Patriarchatu Ekumenicznego Konstantynopola sięgają dopiero 1967 r., kiedy to po raz od ,prehistorycznych” prób $\mathrm{z}$ czasu reformacji ${ }^{29}$ pojawiła się inicjatywa rozpoczęcia teologicznej wymiany poglądów między prawosławnymi a luteranami. Rok później uczestnicy IV Konferencji Ogólnoprawosławnej w Chambésy oficjalnie zatwierdzili projekt nawiązania multilateralnego dialogu ekumenicznego ze Światową Federacją Luterańską. ${ }^{30}$

Doktryna prawosławna określiła miejsce ekumenii w kontekście własnej eklezjologii. Prawosławie, inaczej niż model ekumenizmu praktykowany przez luteran, mówiący o dążeniu do pojednanej jednorodności, akcentuje, że autentyczna jedność nie może zaistnieć bez zaistnienia pełnej jedności wiary, czyli jedności życia duchowego, zachowania podstawowych zasad eklezjologicznych oraz jedności Tradycji. Zachodni horyzontalny wymiar ekumenicznych wysiłków zastąpiono koncepcją ekumenizmu w czasie, ${ }^{31} \mathrm{w}$ myśl której Kościoły powinny najpierw głęboko przebadać proces historycznego

29 Te n ż e, Filip Melanchton - prekursor dialogu z Kościołem wschodnim, Gdański Rocznik Ewangelicki t. V, 2011, s. 218.

30 Konferencja odbyła się w dniach 8-15 VI 1968 r.; cyt. za: T. K ał u ż ny, Nowy sobór ogólnoprawosławny - natura, historia przygotowań, tematyka, Kraków 2008.

${ }^{31} \mathrm{~K}$. L e ś n i e w s k i, Ekumenizm w czasie, prawosławna wizja jedności w ujęciu Georgesa Florovsky'ego, Lublin 1995, s. 45-46. 
rozwoju swej doktryny oraz praktyki, a dopiero w kolejnych kroku skonfrontować je z patrystyczną tradycją niepodzielonego chrześcijaństwa pierwszego milenium. Dopiero wówczas będzie możliwa jakakolwiek komparatystyka.

Przełomowe znaczenie dla utworzenia wspólnej komisji luterańsko-prawosławnej miało formalne zaproszenie do podjęcia międzynarodowego dialogu, jakie w 1977 r. wystosował Patriarchat Ekumeniczny. Rok później ŚFL mianowała 14 luterańskich członków komisji. Po trzech spotkaniach przygotowawczych, w 1981 r. odbyło się pierwsze posiedzenie Wspólnej Komisji Prawosławno-Luterańskiej. Odtąd spotykała się ona w odstępach dwuletnich. Plonem pracy Komisji jest sześć krótkich tekstów: Objawienie Boże (1985), Pismo Święte i Tradycja (1987) Kanon i inspiracja Pisma Świętego (1989), Sobory ekumeniczne a autorytet Kościoła i w Kościele (1993), Rozumienie zbawienia w świetle soborów ekumenicznych (1995), Zbawienie, łaska, usprawiedliwienie i współdziałanie (synergia) (1998). ${ }^{32}$

Następnie poruszono kwestię rozumienia Eucharystii podczas spotkania w Paphos w 2008 r. oraz natury i misji Kościoła (Wittenberga 2011). Ponadto uznać należy wysiłek, jaki teolodzy obydwu tradycji włożyli w prace nad soteriologią. Choć formalnie owoce tych wysiłków w postaci uzgodnionego wspólnie stanowiska, zwłaszcza w dokumentach z Krety (1987) i Bad Segeberg (1989), nie są pozbawione rozbieżności, to stanowią ważne świadectwo ekumenicznej debaty. W trakcie dialogu możemy wskazać momenty, gdy jedna ze stron debaty wydawała się nieprzejednana. Przykładowo, stało się tak w rozmowach na temat soteriologii, gdzie teologowie reprezentujący tradycję luterańską wykazali zdecydowanie zdogmatyzowaną postawę opartą na fundamentach reformacyjnej teologii usprawiedliwienia. ${ }^{33}$

Począwszy od sesji plenarnej w Oslo (2002), po ostatnie spotkanie w Wittenberdze (2011), przedstawicielom obydwu tradycji udało się zaświadczyć wspólnym głosem o doświadczeniu zbawczej mocy

32 Cyt. za: K. K a r s k i, Luteranizm $w$ dialogu, s. 24.

33 R. P r a c k i, Luteranie i prawosławni w dialogu, s. 279. 
sakramentów chrztu, bierzmowania i Eucharystii, wyznaczając tym samym kierunek do dalszych prac na przyszłość.

Jak zauważa, ks. Roman Pracki, w tym dialogu spotkały się dwa paradygmaty: prawosławny wzorzec „świętości”, który zakłada nieprzerwaną ciągłość między początkami kerygmatu, a dzisiejszą egzystencją wierzącego i luterański ,paradygmat wiary”. Prawosławie podkreśla, że apostolskość, sukcesja, nieprzerwana i niezmienna struktura liturgii oraz udział wierzącego w ofierze Chrystusa przez Eucharystię, konstytuują pryncypia Kościoła. Luterański paradygmat „wiary” wydaje się znajdować na odwrotnym biegunie, przez co wręcz implikuje swego rodzaju ,ideę nieciągłości”, interpretując tym samym wydarzenia biblijne, które zyskują znaczenie jedynie w przestrzeni kontekstu Pisma Świętego.

Luterańska formuła sola Scriptura, jak również koncepcja niepowtarzalności ofiary Chrystusa w Eucharystii, jak również brak zainteresowania adiaforycznym charakterem obrzędów i struktur kościelnych, zdają się korespondować ze wspomnianą wyżej „ideą nieciągłości”. Od 2011 r. Komisja luterańsko-prawosławna nie spotkała się, możemy stwierdzić, że aktualnie nastąpiło zawieszenie dialogu, który to stan przez stronę prawosławną uznawany jest jako zawiniony ze strony luteran, którzy idąc $\mathrm{w}$ kierunku liberalizmu współczesnego świata, odeszli od niezmiennych idei ewangelicznych.

Reasumując ten ciekawy, acz niezmiernie trudny dialog, nie wydaje się możliwe, by luteranie mogli świętować Jubileusz 500-lecia reformacji z braćmi i siostrami z Kościołów prawosławnych.

Rodzi się więc pytanie, czy luteranie będą w stanie wspólnie uczcić 500. rocznicę reformacji z braćmi i siostrami z Kościoła rzymskokatolickiego.

\section{Dialog luterańsko-rzymskokatolicki}

W 1965 r. został formalnie zapoczątkowany dialog między Światową Federacją Luterańską oraz Kościołem rzymskokatolickim. Tym samym bieżącym roku obchodzimy 50. rocznicę tego unikatowego w skali ekumenicznych dialogów bilateralnych - spotkania dwóch 
tradycji konfesyjnych. Dialog luterańsko-rzymskokatolicki, jeśli chodzi zarówno o kryteria ilościowe, czyli liczbę dokumentów, jak też biorąc pod uwagę ich znaczenie, stał się w ciągu owych 50 lat, najbardziej rozwijającym się forum zbliżenia pomiędzy podzielonymi Kościołami. Żaden inny z dialogów bilateralnych nie może poszczycić się sformułowaniem tak przełomowego dokumentu, jakim jest Wspólna Deklaracja w sprawie nauki o usprawiedliwieniu z 1999 r. ${ }^{34}$

Literatura przedmiotu ${ }^{35}$ opisuje funkcjonowanie dialogu luterańsko-katolickiego w czterech fazach. Pierwsze lata pracy wspólnej Komisji zostały zakończone opublikowaniem Raportu z Malty w 1972 r. zatytułowanego Ewangelia a Kościót. W dokumencie tym, który poświęcony był przede wszystkim pojmowaniu Pisma i Tradycji, po raz pierwszy zostało wyrażone przekonanie, że w nauce o usprawiedliwieniu obydwa Kościoły dostrzegają możliwość konsensu, jak też urząd papieski może być widzialnym znakiem jedności Kościoła. ${ }^{36}$

Druga faza dialogu między Kościołami trwała do 1985 r., a najważniejszymi dokumentami tego etapu dyskusji były prace studyjne: Wieczerza Pańska z 1978 r., Urząd duchowny w Kościele z 1981 r., a także dwie deklaracje z okazji jubileuszów reformacyjnych: Wszyscy pod jednym Chrystusem z 1980 r. oraz Marcin Luter -świadek Jezusa Chrystusa wydana w rocznicę urodzin reformatora w $1983 \mathrm{r}$. Był to pierwszy ewangelicki okrągły jubileusz, który spotkał się z odzewem po stronie katolickiej.

VII Zgromadzenie Ogólne Światowej Federacji Luterańskiej, które obradowało w Budapeszcie w 1984 r., sformułowało zadania dla trzeciej fazy dialogu bilateralnego: „Podczas trwania trzeciej fazy dialogu teologicznego tematy trzeba sformułować w taki sposób, aby

34 Deklaracja o usprawiedliwieniu. Historia powstania, tekst deklaracji, opnie, komentarze, Bielsko-Biała 2000.

35 W poniższej analizie odwołuje się do części wyników badań własnych; zob. M. H i n t z, Możliwość luterańsko-katolickiego dialogu ekumenicznego na płaszczyźnie etycznej, Roczniki Teologiczne KUL LI (2004) z. 7, s. 41-56.

36 K. Kar s k i, Luteranizm $w$ dialogu, s. 25. 
z wyrażonego konsensu lub opracowanych konwergencji wynikały konsekwencje dla wspólnoty kościelnej”. ${ }^{37}$

Ta faza dialogu została zdominowana dyskusją na temat istoty Kościoła w świetle nauki o usprawiedliwieniu i nauki o sakramentach. ${ }^{38}$ Wspólna komisja pracowała do 1993 r. W ramach prac na nowo podjęto problem konsensu w nauce o usprawiedliwieniu, temat, który był już reflektowany przez Raport z Malty z 1972 r. W tej fazie dialogu rozpoczęto na szerszą skalę rozmowy na płaszczyznach Kościołów lokalnych. W 1985 r. ukazał się dokument relacjonujący przebieg dyskusji w USA pod tytułem: Usprawiedliwieni przez wiarę, a w Niemczech opublikowano studium Czy potepienia doktrynalne z okresu Reformacji sq $w$ dalszym ciagu czynnikiem podtrzymujacym podziat kościelny?

Podsumowaniem trzeciej fazy dialogu między Kościołem luterańskim a rzymskokatolickim było studium z 1993 r. zatytułowane Kościót i Usprawiedliwienie. Rozumienie Kościoła w świetle nauki o usprawiedliwieniu. Raport z trzeciej fazy Międzynarodowego Dialogu Luterańsko-Rzymskokatolickiego. Jest to najobszerniejszy ze wszystkich dokumentów wypracowanych przez wspólną Komisję. Dokument ten został przetłumaczony na język polski i ukazał się w „Studiach i Dokumentach ekumenicznych”. Omówione w nim zostały w 5 rozdziałach najważniejsze kwestie związane z parą pojęć: „Kościół” i „usprawiedliwienie”. Wskazano w nim na wspólne elementy w rozumieniu Kościoła, jak też uwypuklono kwestie sporne. ${ }^{39}$ Jak podkreśla o. Andrzej Napiórkowski, w dokumencie zostało wyrażone wspólne fundamentalne przekonanie, co do kryteriologicznej

37 Cyt. za: Kościót i Usprawiedliwienie. Rozumienie Kościoła w świetle nauki o usprawiedliwieniu. Raport z trzeciej fazy Międzynarodowego Dialogu Luterańsko-Rzymskokatolickiego (1993). Przedmowa, Studia i Dokumenty Ekumeniczne 36(1995)2, s. 46.

38 A. A. N a p ió r k ow s k i, Usprawiedliwienie grzesznika. Czy potępienia doktrynalne z XVI w. zachowują nadal swoja ważność, Kraków 1998, s. 38.

${ }^{39}$ H. M e y e r, Kościót i usprawiedliwienie. Uwagi do Raportu końcowego trzeciej fazy międzynarodowego dialogu katolicko-luterańskiego, Studia i Dokumenty Ekumeniczne 35(1995)1 s. 13-18. 
funkcji nauki o usprawiedliwieniu. ${ }^{40}$ Dokument Usprawiedliwienie i Kościól, w swym założeniu, był raportem. Nie miał więc aspiracji do bycia wspólnym dokumentem teologicznym dwóch tradycji kościelnych. Był zresztą zbyt długi i drobiazgowy, a w swym stylu zbyt naukowy i przez to niemożliwy do recepcji dla szerokich kręgów kościelnych.

Wspólna Komisja postawiła sobie więc za cel, niejako na kanwie owego raportu, wypracowanie wspólnego dokumentu-oświadczenia na temat nauki o usprawiedliwieniu, gdzie zostałoby jasno powiedziane, że Kościoły akcentują inaczej pewne tematy, ale wyznają taką samą naukę o usprawiedliwieniu.

Po dwóch latach, w 1995 r., ukazała się pierwsza redakcja tego tekstu. Druga redakcja dokumentu o usprawiedliwieniu, uwzględniająca dotychczasowe uwagi strony katolickiej i luterańskiej powstała w czerwcu 1996 r. Wówczas wyrażano w kręgach luteran europejskich przekonanie, że dokument zostanie zaakceptowany przez Zgromadzenie Ogólne Światowej Federacji Luterańskiej w Hongkongu w lipcu 1997 r. Jednakże już na posiedzeniu Rady ŚFL pod koniec września 1996 r. zwrócono się do Komisji o przepracowanie dokumentu, czego wynikiem jest tzw. wersja ostateczna z lutego 1997 r., która została rozesłana do Kościołów członkowskich wraz z listem sekretarza generalnego ŚFL. Rada Federacji, przez sekretarza generalnego, apeluje w tym liście o ostateczną decyzję w sprawie dokumentu. List ten zaznacza, że po akceptacji tego tekstu, będzie to „oznaczało decydujący krok w kierunku przezwyciężenia podziału pomiędzy Kościołami luterańskimi a Kościołem Rzymskokatolickim". ${ }^{41}$ Autor listu pisze dalej, że tekst zaaprobują „,właściwe gremia Kościoła Rzymskokatolickiego", nie precyzuje jednakże, o kogo chodzi. Powyższy przebieg procesu akceptacji tekstu przez obie strony, zwłaszcza przez stronę luterańską, ukazuje, jak skomplikowany jest ów proces ratyfikacji

\footnotetext{
40 A. A. N a p i ó r k o w s k i, Usprawiedliwienie grzesznika, s. 41.

${ }^{41}$ List okólny Sekretarza Generalnego ŚFL Ishmaela Noko do Kościołów członkowskich i Komitetów Narodowych ŚFL z dnia 27 lutego 1997, tłum. A. D ę b s k i, Archiwum KEA w RP.
} 
w przypadku funkcjonowania głównego reprezentanta rodziny luterańskiej jako Federacji niezależnych Kościołów. W toku dialogu, nie do końca było też dla strony luterańskiej klarowne, kto parafuje ów dokument ze strony Kościoła rzymskokatolickiego. Ostatecznie podpisali go w imieniu Kościoła rzymskokatolickiego na uroczystości w Augsburgu 31 października 1999 r. przewodniczący i sekretarz Papieskiej Rady ds. Jedności Chrześcijan. Wielu ewangelików miało jednak nadzieję, że to sam zwierzchnik Kościoła złoży swój podpis na tekście dokumentu.

Tak zwana czwarta faza dialogu bilateralnego nie miał już tak dynamicznego charakteru, była formalnie prowadzona w latach 19952006 i zakończyła się opublikowaniem dokumentu Apostolskość Kościoła w 2006 r. Niestety, stwierdzić, trzeba, że obecnie mamy do czynienia z zastojem w pracy teologicznej partnerów dialogu.

Za kolejny przełom w budowaniu wzajemnych relacji można uznać Raport luterańsko-rzymskokatolickiej Komisji Dialogu ds. Jedności z 2013 r. zatytułowany: Luterańsko-katolickie upamiętnienie Reformacji w 2017 roku. Raport ukazał się w polskim tłumaczeniu w wersji drukowanej oraz w Internecie jako PDF. ${ }^{42}$

\section{Szanse ekumenicznych obchodów jubileuszu reformacji Anno Domini 2017}

Od konfliktu do komunii. Luterańsko-katolickie upamiętnienie Reformacji w 2017 roku. Raport luterańsko-rzymskokatolickiej Komisji Dialogu ds. Jedności jest najważniejszym drogowskazem na drodze do ekumenicznej celebracji wielkiego jubileuszu protestanckiego świata. Dokument ten spotkał się także z recepcją w Polsce, również po stronie katolickiej. Stanowi punkt wyjścia do dyskusji nad możliwymi kierunkami wspólnych działań w 2017 r.

42 http://www.lutheranworld.org/sites/default/files/FCTC_Polish_od_konfliktu_do_komunii-20131121.pdf; http://www.cme.org.pl/files/2013/od_konfliktu_do_komunii_20.11-www.pdf; http://luter2017.pl/wp-content/uploads/pdf/ pdfodkonfliktudokomunii.pdf. 
Opiniotwórcze czasopismo „Niedziela. Tygodnik katolicki” stwierdza: „Opublikowany 17 czerwca 2013 r. przez Kościół katolicki i Światową Federację Luterańską, dokument liczy 90 stron. Uznaje wspólną odpowiedzialność za podziały w Kościele zachodnim w XVI w. Analizuje też główne myśli Marcina Lutra w perspektywie ekumenicznego dialogu między dwoma wyznaniami". ${ }^{43}$ Jednocześnie częstochowski periodyk przywołuje często cytowane stwierdzenie kard.Kurta Kocha, od lipca 2010 r. przewodniczącego Papieskiej Rady ds. Popierania Jedności Chrześcijan: „Obchodząc rocznicę reformacji «nie możemy świętować podziału Kościoła», ale możemy «spróbować poszukać dróg do wspólnej przyszłości»". ${ }^{44}$

W Polsce chętnie cytowano też inne słowa kard. Kocha, który ostrzegł przed pospiesznym ekumenizmem, czyli postępowaniem, zgodnie z zasadą legendarnego austriackiego aktora kabaretowego Helmuta Qualtingera. Jego dewiza brzmiała: „Wprawdzie nie wiem, dokąd chcę dojść, ale za to jestem tam szybciej”. „To nie jest droga, którą powinien iść ekumenizm" - powiedział Koch podczas wykładu wygłoszonego 17 grudnia 2011 r. w Rzymie. ${ }^{45}$

Jak więc te słowa szwajcarskiego teologa, który w 2009 r. współuczestniczył w pracach nad przywołanym Raportem, mają się do zawartości tego dokumentu? Dokument składa się z 6 rozdziałów, każda kwestia ma swój odrębny numer, w sumie jest ich 245. Raport omawia najpierw kwestię upamiętnienia reformacji w epoce ekumenizmu. Następnie referuje aspekty teologiczne i historyczne tło reformacji, próbując zmierzyć się z wieloma stereotypami obecnymi po obu stronach dialogu. Rozdział V wyraża wezwanie do wspólnego upamiętnienia jubileuszu przez modlitwę i wyznanie grzechów przeciwko jedności Kościoła. Rozdział VI zawiera 5 ekumenicznych imperatywów oraz krótkie komentarze do nich. Ze względu na ich

43 http://www.niedziela.pl/artykul/5264/Genewa-ogloszono-katolicko-luteranski (dostęp: 18 VI 2013).

${ }^{44}$ Tamże.

45 http://info.wiara.pl/doc/1034983.Kard-Koch-To-nie-droga-ekumenizmu (dostęp: 20 X 2014). 
syntetyczny charakter oraz doniosłość, przywołać należy treść owych imperatywów in extenso.

„Pierwszy imperatyw: katolicy i luteranie powinni zawsze obierać jako punkt wyjścia perspektywę jedności a nie rozłamu, aby wzmacniać to, co mają wspólnego, nawet jeśli łatwiej jest dostrzegać i doświadczać różnice.

Drugi imperatyw: luteranie i katolicy muszą pozwalać sobie ciągle się zmieniać poprzez spotkanie ze sobą nawzajem i wspólne świadectwo wiary.

Trzeci imperatyw: katolicy i luteranie powinni się na nowo zobowiązać do poszukiwań widzialnej jedności; wspólnie wypracować plan, uwzględniający konkretne kroki, które miałyby do niej prowadzić, i wciąż na nowo do tego celu dążyć.

Czwarty imperatyw: luteranie i katolicy muszą wspólnie ponownie odkryć siłę Ewangelii Jezusa Chrystusa dla naszych czasów.

Piąty imperatyw: katolicy i luteranie powinni w zwiastowaniu oraz służbie światu składać świadectwo o łasce Bożej". ${ }^{46}$

Jako swoisty komentarz do całości Raportu może posłużyć ostatnie zdanie, czyli kwestia nr 245: „Upamiętnienie początków Reformacji będzie odpowiednie wtedy, gdy luteranie i katolicy wspólnie wsłuchają się w Ewangelię Jezusa Chrystusa i gdy pozwolą się wciąż na nowo powoływać do wspólnoty ze swoim Panem. Wówczas będą zjednoczeni we wspólnym posłannictwie, jak opisuje to Wspólna Deklaracja o Usprawiedliwieniu: «Luteranie i katolicy uznają za swój wspólny cel wyznawanie we wszystkim Chrystusa; tylko Jemu ponad wszystko należy ufać jako jedynemu Pośrednikowi» (ITm 2,5), przez którego Bóg w Duchu Świętym daje nam samego siebie i obdarza swoimi odnawiającymi darami" (Wspólna Deklaracja 18)". ${ }^{47}$

46 Od konfliktu do komunii, s. 87-88.

47 Tamże. s. 89. 
Dzieło Reformy Kościoła 1517 r. miało służyć całemu chrześcijaństwu, a zwłaszcza naprawie stanu zachodniego chrystianizmu, ową intencję zauważają dzisiaj nie tylko ekumeniści, ale również historycy Kościoła. ${ }^{48}$ Konstatacja ta nie musi jednak prowadzić do uznania potrzeby czy wręcz możliwości „świętowania” jubileuszu. Jak zauważa o. Wysokiński, dla katolików reformacja była ,jednak rozbiciem Kościoła i odejściem od jego katolickich założeń". ${ }^{99}$ Ów pogląd wpisuje się w myśl teologiczną kard. Kocha.

Kardynał Koch był w grudniu 2014 r. w Polsce. Podczas spotkania w Kamieniu Śląskim wygłosił referat na temat zasad ekumenizmu, ${ }^{50}$ nie padła w nim żadna deklaracja na temat możliwości wspólnego przeżywania roku 2017, co więcej referat ten wywołał wśród polskich luteran odczucie, że dialog ekumeniczny znajduje się w fazie ochłodzenia. ${ }^{51}$

Obok głosu aktualnego przewodniczącego Papieskiej Rady ds. Popieranie Jedności Chrześcijan, należy przywołać pogląd kard. Waltera Kaspera promującego ekumenizm duchowy. ${ }^{52}$ Ową otwartość na dialog i poszukiwanie punktów wspólnych w obchodach jubileuszu reformacji wskazywał już kard. Kasper w tekście z 2003 r. ${ }^{53}$ Kasper

48 To nie byt czas Franciszka w Kościele. Z historykiem Kościoła Ireneuszem Wysokińskim OP rozmawia Włodzimierz Bogaczyk, W drodze 4/2015, s. 101-111.

49 Tamże, s. 100.

50 Ekumeniczne sympozjum w Kamieniu Śląskim 12 grudnia 2014, http://ekumenia. pl/aktualnosc/ekumeniczne-sympozjum-w-kamieniu-slaskim/(dostęp: 23 III 2015).

51 J. S a m i e c, Cel ekumenii pogrążony we mgle, Blog biskupa Jerzego Samca, http://blogbiskupa.luteranie.pl/2014/12/cel-ekumenii-pograzony-mgle/ (dostęp: 16 XII 2014).

52 W. H u b e r, Überlegungen zum Stand der Ökumene - Vortrag vor der Hamburgischen Kommende des Johanniterordens 25. August 2007, http://www. ekd.de/print.php?file=/vortraege/huber/070825_huber_hamburg.html (dostęp: 20 III 2015).

53 W. K a s p e r, Gegenwärtige ökumenische Situation und künftige Perspektiven der Ökumene, Materialdienst des Konfessionskundlichen Instituts Bensheim 4/2003, s. 68-75. 
mówi o innym paradygmacie rozumienia Kościoła, co nie wyklucza wspólnego składania świadectwa wiary przed światem. ${ }^{54}$

Obchody roku 2017 mogą się stać manifestacją wiary chrześcijan w sekularyzującym się świecie, gdyż, jak podkreślają niemieccy luteranie $\mathrm{w}$ dokumencie z 2010 r., to sekularyzacja jest dzisiaj największym wyzwaniem dla całego zachodniego chrześcijaństwa. ${ }^{55}$ By takie wspólne składanie świadectwa w 2017 r. mogło w ogóle zaistnieć, potrzebna jest wpierw rzetelna teologiczna debata. Niniejszy tekst wskazał tym samym na potrzebę takiej dyskusji w polskim kontekście ekumenicznym. Wielką szkodą dla ruchu ekumenicznego i całościowego chrześcijańskiego świadectwa wobec trendów sekularyzmu może być scenariusz, w którym ewangelicy samotnie obchodzić będą rocznicę powstania trzeciej co wielkości rodziny konfesyjnej chrześcijaństwa.

bp Marcin HINTZ

54 Te n że, Wege der Einheit. Perspektiven für die Ökumene, Freiburg im Breisgau 2005.

55 J. Tr a ck, O. S c hu eng r a f (red.), Säkularisierung. Eine ökumenische Herausforderung für die Kirchen. Eine Ökumenische Studie des Ökumenischen Studienausschusses der VELKD und des DNK/LWB, Hannover 2010. 